\title{
Improving Learning Outcomes by Using Quizizz Educational Game Assisted Learning Video Media
}

\author{
Anik Hariyastuti \\ SD Negeri Adiwerna 01, Kabupaten Tegal \\ anikhariyatuti@gmail.com
}

\section{Article History}

accepted 01/11/2020

approved 08/11/2020

published 15/11/2020

\begin{abstract}
This study aims to determine the increase in learning outcomes in online learning through learning video media assisted by quiziz educational games. This research is a classroom action research with 29 students of class V SDN Adiwerna 01 as the research subjects. This research was conducted in 2 cycles, each cycle of 2 meetings. Each meeting consists of 4 stages, namely planning, implementing, observing and reflecting. The implementation of the research stages is slightly different from classroom learning because learning is carried out separately or students are in their respective homes. Based on the results of the research, in the first cycle, the average student learning outcomes were 72.07 with $72 \%$ student completeness success, still below the $85 \%$ success indicator. Whereas in cycle II the average student learning outcomes were 82, 07 and the completeness success increased to $93 \%$ in this case it was more than the $85 \%$ achievement indicator. So from cycle I and cycle II there was an increase in student learning outcomes. So, in this study it can be concluded that using video learning media assisted by quiziz educational games can improve student learning outcomes in online learning science subjects human digestive organs material.
\end{abstract}

Keywords: Learning Outcomes, Video Media, Quizizz Educational Games

\begin{abstract}
Abstrak
Penelitian ini bertujuan untuk mengetahui peningkatan hasil belajar dalam pembelajaran daring melalui media video pembelajaran berbantuan game edukasi quiziz. Penelitian ini merupakan penelitian tindakan kelas dengan subyek penelitian siswa kelas V SDN Adiwerna 01 sebanyak 29 orang. Penelitian ini dilaksanakan 2 siklus, masing-masing siklus 2 kali pertemuan. Setiap pertemuan terdiri dari 4 tahap yaitu perencanaan, pelaksanaan, observasi dan refleksi. Pelaksanaan tahap-tahap penelitian sedikit berbeda dari pembelajaran dalam kelas karena pembelajara dilakukan secara terpisah atau siswa berada dirumah masing-masing. Berdasarkan hasil penelitian, pada siklus I diperoleh rata-rata hasil belajar siswa secara klasikal 72,07 dengan keberhasilan ketuntasan siswa $72 \%$ masih dibawah indikator keberhasilan $85 \%$. Sedangkan pada siklus II diperoleh rata-rata hasil belajar siswa secara klasikal 82, 07 dan keberhasilan ketuntasan meningkat menjadi $93 \%$ dalam hal ini sudah lebih dari indikator ketercapaian $85 \%$. Jadi dari siklus I dan siklus II terjadi peningkatan hasil belajar siswa. Sehingga, dalam penelitian ini dapat disimpulkan bahwa dengan menggunakan media video pembelajaran berbantuan game edukasi quiziz dapat meningkatkan hasil belajar siswa dalam pembelajaran daring mata pelajaran IPA materi organ pencernaan manusia.
\end{abstract}

Kata kunci: Hasil Belajar, Media Video, Game Edukasi Quizizz

Social, Humanities, and Education Studies (SHEs): Conference Series https://jurnal.uns.ac.id/shes

p-ISSN 2620-9284

e-ISSN 2620-9292 


\section{PENDAHULUAN}

Belajar adalah kegiatan utama dari keseluruhan proses pendidikan di sekolah yang bertujuan untuk menghasilkan perubahan tingkah laku. Perubahan itu meliputi ranah kognitif, ranah afektif dan ranah psikomotor. Kegiatan pembelajaran memerlukan motivasi belajar, keaktifan belajar, partisipasi dan komunikasi interaktif antara guru dan peserta didik. Pembelajaran dalam hal ini berkaitan dengan materi proses pencernaan dalam tubuh manusia, dimana siswa harus dapat mendeskripsikan organ-organ pencernaan pada manusia dengan benar serta mempresentasikan alur perjalanan makanan pada sistem organ pencernaan manusia dengan runtut dan benar.

Pada saat melakukan pembelajaran daring, respon dan keaktifas siswa sangat kurang ketika mengerjakan tugas dan saat menjawab soal-soal evaluasi pada meteri organ pencernaan manusia. Hal tersebut terjasi karena saat pembelajaran guru masih mengajar menggunakan model pembelajaran yang monoton dan cenderung tidak menyenangkan dengan hanya memberi materi, berdiskusi dan penugasan melalui WAG saja kemudian siswa mengerjakan. Sehingga tersebut berpengaruh terhadap hasil belajar siswa. Berdasarkan pengamatan awal yang dilakukan di SD Negeri Adiwerna 01, Kecamatan Adiwerna, Kabupaten Tegal pada siswa kelas $\mathrm{V}$ diperoleh keterangan bahwa nilai hasil belajar evaluasi siswa pada pembelajaran IPA pada materi organ pencernaan manusia tahun pelajaran 2020/2021 masih rendah. Dari hasil pengamatan tersebut diketahui bahwa jumlah keseluruhan siswa kelas $\mathrm{V}$ sebanyak 29 siswa dengan KKM yang ditetapkan yaitu 70 , hanya 11 siswa yang memperoleh nilai $\geq 70(38 \%)$ dan 18 siswa memperoleh nilai $\leq 70(62 \%)$. Berdasarkan permasalahan di atas, hasil pembelajaran IPA di SDN Adiwerna 01 dapat dikatakan kurang berhasil.

Hal ini menjadi tantangan bagi guru untuk tetap dapat menciptakan pembelajaran yang menyenangkan, menarik, aktif dan efektif yang nantinya akan berpengaruh terhadap peningkatan hasil belajar siswa.. Meskipun pembelajaran dilaksanakan jarak jauh atau daring, guru harus mampu meningkatkan motivasi siswa dalam belajar. Motivasi siswa dapat tercipta melalui penerapan media pembelajaran yang menarik. Salah satu media pembelajaran yang menarik dalam pembelajaran daring adalah memanfaatkan pembelajaran dengan menggunakan video pembelajaran untuk meningkatkan hasil belajar siswa.. Hal itu sesuai dengan pendapat Cheppy Riyana (2007) media video pembelajaran adalah media yang menyajikan audio dan visual yang berisi pesan-pesan pembelajaran baik yang berisi konsep, prinsip, prosedur, teori aplikasi pengetahuan untuk membantu pemahaman terhadap suatu materi pembelajaran.

Selain dengan video pembelajaran untuk menarik minat dan motivasi siswa saat mengerjakan soal-soal evaluasi perlu menggunakan platform yang menarik yaitu game edukasi quizizz. Game edukasi quizizz ini bisa menggunakan laptop atau smartpone dan dapat dilaksanakan dimanapun dan kapanpun.

Berdasarkan uraian diatas, tujuan dilakukannya peneliyian ini antara lain : untuk mengetahuai upaya pemingkatan hasil belajar IPA materi organ pencernaan manusia dengan menggunakan media video pembelajaran berbantuan game edukasi quizizz pada pembelajaran daring siswa kelas V SD Negeri Adiwerna 01. Selain itu untuk meningkatkan hasil belajar IPA materi organ pencernaan manusia dengan menggunakan video pembelajaran berbantuan game edukasi quizizz pada pembelajaran daring pada siswa kelas V SDN Adiwerna 01.

\section{METODE}

Metode penelitian yang digunakan dalam penelitian ini adalah penelitian tindakan kelas untuk meningkatkan hasil belajar siswa dalam pembelajaran daring melalui media video pembelajaran berbantuan game edukasi quiziz mata pelajaran IPA materi organ pencernaan manusia. Data yang diperoleh kemudian dianalisis menggunakan 
analisis diskriptif komparatif yaitu membandingkan nilai tes evaluasi setelah siklus I dan siklus. Data kuantitatif dalam penelitian ini adalah evaluasi hasil belajar siswa. Langkah pertama dalam proses pengolahan hasil belajar adalah penskoran dari data berdasarkan hasil belajar siswa. Penskoran adalah proses pengubahan jawabanjawaban soal tes menjadi angka-angka. Angka-angka hasil penilaian tersebut selanjutnya diubah menjadi nilai-nilai untuk mengetahui gambaran yang jelas mengenai hasil belajar siswa dalam pembelajaran IPA.

Penelitian ini dilakukan pada mata pelajaran IPA materi organ pencernaan manusia. Subyek penelitian adalah siswa kelas V SDN Adiwerna 01 yang melibatkan 29 siswa yang dilaksanakan pada bulan Oktober dan Nopember 2020. Instrumen pengumpulan data adalah tes evaluasi hasil belajar sedangkan teknis analisis data menggunakan teknik analisis deskriptif kualitatif dan kualitatif menggunakan kreteria pencapaian ketuntasan dengan indikator ketercapaian $85 \%$.

\section{HASIL DAN PEMBAHASAN}

Dalam Penelitian Tindakan Kelas (PTK) ini menggunakan 2 siklus. Siklus aktivitas dalam PTK diawali dengan perencanaan tindakan (planning), penerapan tindakan (action), mengobservasi proses tindakan (observation), dan melakukan refleksi (reflection), dan seterusnya sampai perbaikan atau peningkatan yang diharapkan tercapai (kriteria keberhasilan).

Pada penelitian ini rencana tindakan dalam 2 siklus dengan menggunakan media video pembelajaran berbatuan game edukasi quizizz dan dalam satu pertemuan tersebut digunakan untuk evaluasi pembelajaran. Apabila proses pembelajaran pada siklus I belum tuntas atau belum mencapai hasil yang diharapkan maka peneliti akan melanjutkan ketahap siklus berikutnya sampai hasil yang didapatkan tercapai dengan maksimal.

Pada siklus I persentase rata-rata aktivitas belajar siswa dengan menggunakan media video pembelajaran berbantuan game edukasi quizizz dengan persentase $73 \%$. Dalam hal ini taraf keberhasilan belajar siswa termasuk dalam kategori cukup baik. Dari hasil perbaikan pembelajaran yang telah dilaksanakan pada pembelajaran siklus I diperoleh hasil analisis pengamatan tes evaluasi pelaksanaan pembelajaran pada siklus I yang telah dilakukan yang tersaji pada tabel di bawah ini :

Tabel 1. Ketuntasan Klasikal Siklus I

\begin{tabular}{cccc|}
\hline Nilai & Banyaknya Siswa & Persentase & Keterangan \\
\hline$<70$ & 8 & $28 \%$ & Tidak Tuntas \\
$\geq 70$ & 21 & $72 \%$ & Tuntas \\
\hline
\end{tabular}

Dari tabel di atas yaitu tabel ketuntasan hasil belajar siswa dapat diperjelas pada diagram di bawah ini:

Ketuntasan Klasikal Siklus 1

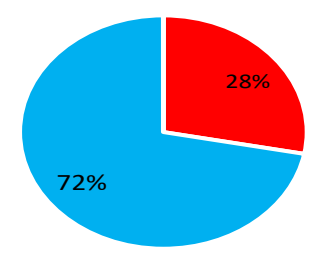

Gambar 1. Diagram Ketuntasan Klasikal Siklus I 
Gambar diatas menunjukkan perbandingan persentase ketuntasan hasil belajar IPA siklus I. Siswa yang tuntas berjumlah 21 siswa atau $72 \%$ dari jumlah keseluruhan siswa dan siswa yang tidak tuntas berjumlah 8 siswa atau $28 \%$ dari jumlah keseluruhan siswa. Secara keseluruhan ketuntasan hasil belajar IPA pada siklus I, siswa yang mendapat nilai di atas KKM 70 masih kurang dari persentase $85 \%$ dari jumlah keseluruhan siswa.

Persentase rata-rata aktivitas belajar siswa dengan menggunakan media video pembelajaran berbantuan game edukasi quizizz adalah $89 \%$. Dalam hal ini taraf keberhasilan belajar siswa termasuk dalam kategori baik.

Dari hasil perbaikan pembelajaran yang telah dilaksanakan pada pembelajaran siklus II diperoleh hasil analisis pengamatan tes pelaksanaan pembelajaran pada siklus II yang telah dilakukan yang tersaji pada tabel 2 di bawah ini:

Dari data tabel dan grafik di atas maka dibuat tabel ketuntasan klasikal siklus II sebagai berikut :

Tabel 2 Ketuntasan Klasikal Siklus II

\begin{tabular}{cccc}
\hline Nilai & Banyaknya Siswa & Persentase & Keterangan \\
& & & \\
\hline 70 & 2 & $7 \%$ & Tidak Tuntas \\
$\geq 70$ & 27 & $93 \%$ & Tuntas \\
\hline
\end{tabular}

Dari tabel di atas yaitu tabel ketuntasan hasil belajar siswa dapat diperjelas pada diagram di bawah ini:

\section{KETUNTASAN KLASIKAL SIKLUS II}

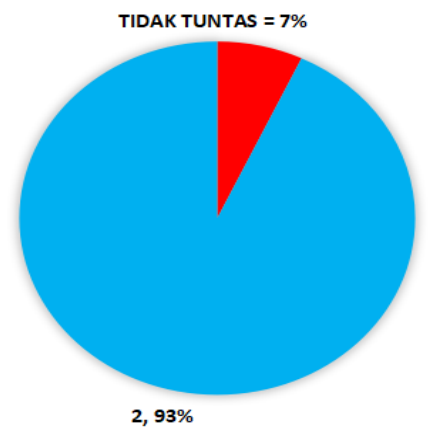

Gambar 2 Diagram Ketuntasan Klasikal Siklus II

Gambar 4.6 menunjukkan perbandingan persentase ketuntasan hasil belajar IPA siklus II. Siswa yang tuntas berjumlah 29 siswa atau $93 \%$ dari jumlah keseluruhan siswa dan siswa yang tidak tuntas berjumlah 2 siswa atau $7 \%$ dari jumlah keseluruhan siswa. Dari hasil data siklus II tersebut sudah menunjukkan keberhasilan belajar siswa yang sudah sesuai dengan indikator keberhasilan penelitian dan mengalami peningkatan setelah menggunakan media video pembelajaran berbatuan game edukasi quizizz.

Penggunaan media video pembelajaran berbantuan game edukasi quizizz dapat meningkatkan hasil belajar belajar IPA. Hasil evaluasi pembelajaran dari setiap pembelajaran yang dilakukan selalu mengalami peningkatan. Sebelum menggunakan media video pembelajaran berbatuan game edukasi quizizz persentase keberhasilan ketuntasan hanya sebesar $38 \%$. Pembelajaran siklus I dengan menggunakan media video pembelajaran berbantuan game edukasi quizizz keberhasilan ketuntasan mengalami peningkatan dengan persentase keberhasilan sebesar $72 \%$. Pada pembelajaran siklus II dengan menggunakan media video pembelajaran berbantuan game edukasi quizizz mengalami peningkatan dengan persentase keberhasilan 
ketuntasan sebesar 93\% diatas indikator keberhasilan $85 \%$. Peningkatan nilai ratarata siswa dari pra siklus 64,14 menjadi 72,07 pada siklus I dan meningkat menjadi 82,07 pada siklus II.

Peningkatan langkah tersebut sesuai dengan teori yang diungkap oleh Cheppy Riyana (2007) bahwa media video pembelajaran adalah media yang menyajikan audio dan visual yang berisi pesan-pesan pembelajaran baik yang berisi konsep, prinsip, prosedur, teori aplikasi pengetahuan untuk membantu pemahaman terhadap suatu materi pembelajaran. Video merupakan bahan pembelajaran tampak dengar (audio visual) yang dapat digunakan untuk menyampaikan pesan-pesan/materi pelajaran. Dikatakan tampak dengar kerena unsur dengar (audio) dan unsur visual/video (tampak) dapat disajikan serentak. Sedangkan game quizizz adalah aplikasi pendidikan berbasis game, yang membawa aktivitas multi pemian ke ruang kelas dan membuatnya di kelas latihan interaktif dan menyenangkan (Purba. 2019: 5). Jadi dengan menerapkan video pembelajaran berbantuan game edukasi quizizz dalam penelitian tindakan kelas ini dapat meningkatkan pemahaman siswa serta memotivasi siswa saat pembelajaran, sehingga pembelajaran menjadi lebih bermakna dan menyenangkan serta hasil belajar IPA materi organ manusia dapat meningkat.

\section{SIMPULAN}

Media video pembelajaran berbantuan game edukasi quizizz dalam pembelajaran IPA materi organ pencernaan manusia pada siswa kelas $V$ SDN Adiwerna 01 penerapan pada penelitian tindakan kelas pada saat pembelajaran siklus I dan siklus II di kegiatan inti pembelajaran, dimana siswa menyimak video pembelajaran tentang organ pencernaan manusia. Pada kegiatan penutup siswa diajak untuk mengerjakan soal tes evaluasi dengan menggunakan platform game edukasi quizizz. Dengan menggunakan video pembelajaran berbantuan game edukasi quizizz pembelajaran lebih interaktif, bermakna dan menyenangkan. Sehingga proses pembelajaran lebih hidup dan siswa terlihat sangat aktif dan antusias.

Berdasarkan hasil penelitian tindakan kelas yang telah dilaksanakan dapat ditarik kesimpulan sebagai berikut: Penggunaan media video pembelajaran berbantuan game edukasi quizizz dapat meningkatkan hasil belajar IPA materi organ pencernaan manusia pada pembelajaran daring siswa kelas V SD Negeri Adiwerna 01, Kecamatan Adiwerna, Kabupaten Tegal Semester I Tahun Pelajaran 2020/2021. Hal ini dapat dilihat dari hasil ketuntasan belajar siswa pada pembelajaran pra siklus, siklus I dan siklus II sebagai berikut: pada pra siklus siswa yang tuntas sebanyak 11 siswa atau $38 \%$, pada siklus I siswa yang tuntas sebanyak 21 siswa atau $72 \%$ dan pada siklus II siswa yang tuntas sebanyak 27 siswa atau 93\%.

Berdasarkan hasil pemaparan di atas maka dapat dikatakan bahwa pembelajaran dengan menerapkan media video pembelajaran berbantuan game edukasi quizizz dapat meningkatkan hasil belajar IPA materi organ pencernaan manusia pada pembelajaran daring siswa kelas V SD Negeri Adiwerna 01, Kecamatan Adiwerna, Kabupaten Tegal semester I tahun pelajaran 2020/2021.

Bagi Guru : Guru disarankan untuk memberikan motivasi belajar di dalam kegiatan belajar mengajar, sehingga saat pembelajaran siswa lebih antusias dan tertarik mengikuti pembelajaran IPA terutama pada kompetensi pembuatan suatu karya/model. Dalam melaksanakan pembelajaran, guru disarankan untuk menggunakan media pembelajaran yang sesuai dengan tahap perkembangan siswa SD. Penggunaan media video pembelajaran berbantuan game edukasi quizizz dapat membuat siswa senang dan cepat memahami materi segingga hasil belajar dapat meningkat. Saat menggunakan media video pembelajaran sebaiknya guru juga memperhatikan faktor belajar yang lain untuk mendapatkan proses pembelajaran yang maksimal. 
Bagi Sekolah : Sekolah diharapkan turut berperan dalam upaya meningkatkan hasil belajar siswa, misalnya dengan memberikan sarana dan prasarana yang memadai baik kepada guru atau pun siswa saat melakukan pembelajaran daring di masa pandemi seperti ini.

\section{DAFTAR PUSTAKA}

Aqib, Zainal. (2009). Penelitian Tindakan Kelas untuk Guru. Bandung: Yrama Widya. Aqib. (2011). Pengertian Tindakan Kelas (PTK) Menutur Para Ahli. https://www.pelajaran.co.id/2019/15/pengertian-ptk-tujuan-karakteristik-prinsiplangkah-dan-model-penelitian-tindakan-kelasptk.html\#: :text=Pengertian\%20Penelitian\%20Tindakan\%20Kelas\%20(PTK)\%20 Menurut\%20Para\%20Ahli\&text=Menurut\%20Arikunto\%2C\%20dkk\%2C\%20penel itian\%20tindakan,dalam\%20sebuah\%20kelas\%20secara\%20bersama. Diakses tanggal 13 Oktober 2020.

Ardiansyah, Ivan. (2013). Eksplorasi Pola Komunikasi dalam Diskusi Menggunakan Moddle pada Perkuliahan Simulasi Pembelajaran Kimia, Universitas Pendidikan Indonesia, Bandung-Indonesia

Arikunto, Suharsimi. (2002). Prosedur Penelitian suatu Pendekatan Praktik. Jakarta: Rineka Cipta.

Arikunto, dkk. (2006). Pengertian Tindakan Kelas (PTK) Menutur Para Ahli. https://www.pelajaran.co.id/2019/15/pengertian-ptk-tujuan-karakteristik-prinsiplangkah-dan-model-penelitian-tindakan-kelas-

ptk.html\#: :text=Pengertian\%20Penelitian\%20Tindakan\%20Kelas\%20(PTK)\%20 Menurut\%20Para\%20Ahli\&text=Menurut\%20Arikunto\%2C\%20dkk\%2C\%20penel itian\%20tindakan,dalam\%20sebuah\%20kelas\%20secara\%20bersama Diakses pada tanggal 13 Oktober 2020.

Aunurrahman. (2009). Belajar dan pembelajaran. Bandung: alfabeta.

Cheppy Riyana.(2007). Pedoman Pengembangan Media Video. Bandung:Program. P3AI Universitas Pendidikan Indonesia.

Daryanto. (2010). Media Pembelajaran. Yogyakarta:Gava Media

Dimyati, Mudjiono. (2009). Belajar dan Pembelajaran. Jakarta: Rineka Cipta.

Hamdani. (2011). Strategi Belajar Mengajar. Bandung: Pustaka Setia.

Kunandar. (2008). Langkah Mudah Penelitian Tindakan Kelas. Sebagai Pengembangan Profesi Guru. Jakarta: PT. Raja Grafindo Persada.

Latipah, Eva. (2012). Pengantar Psikologi Pendidikan. Yogyakarta: Pedagogia.

Madya, Suwarsih. (2009). Penelitian Tindakan. Bandung: Alvabeta, cv.

Mardapi, Djemari. (2008). Teknik Penyusunan Instrumen Tes dan Non Tes. Jogjakarta: Mitra Cendikia Pres.

Nanang Hanafiah, \& Cucu suhana. (2009). Konsep Strategi Pembelajaran. Bandung: Refika Aditama.

Natalia. (2012). Penerapan Model Pembelajaran Talking Stick dalam meningkatkan Hasil Belajar Bahasa Indonesia Siswa Kelas V SD N 2 Tataaran. PGSD FKIP UNIMA. Jurnal Penelitian.

Nursalam dan Ferry Efendi. (2008). Pendidikan dalam Keperawatan. Jakarta: Salemba Medika

Poerwanti. Endang. dkk. (2008). Asesmen Pembelajaran SD. Jakarta: Direktorat Jendral Pendidikan Tinggi Departemen Pendidikan Nasional.

Pranoto, Alvini.dkk. 2009. Sains dan Teknologi. Jakarta: PT Gramedia Pustaka Utama.

Purba, L. S. L. (2019). Peningkatan Konsentrasi Belajar Mahasiswa Melalui pemanfaatan Evaluasi Pembelajaran Quizizz Pada Mata Kuliah Kimia Fisika I. JDP. 12(1): 29 
Purwanto. (2009). Evaluasi Hasil Belajar. Yogyakarta: Pustaka Belajar. Republik Indonesia. 2003. Undang-undang Republik Indonesia Nomor 20 Tahun 2003 tentang Sistem Pendidikan Nasional.

Samatowa, Usman. (2010). Pembelajaran IPA di Sekolah Dasar. Jakarta: Inseks.

Sanaky Hujair AH. (2009). Media Pembelajaran. Yogyakarta: Safira Insania Press.

Sanjaya, Wina. (2008). Perencanaan dan Desain Sistem Pembelajaran. Jakarta: Kencana Prenada Media Group.

Slameto. (2003). Belajar dan Faktor - Faktor yang Mempengaruhinya. Jakarta: Rineka Cipta.

Sudjana, Nana. (2005). Penilaian Hasil Proses Belajar Mengajar. Bandung: PT. Remaja Rosdakarya.

Sujana, Janti Gristinawati dan Yuyu Yulia. (2005). Perkembangan Perpustakaan di Indonesia. Bogor: IPB Press.

Suprijono, Agus. (2009). Cooperative Learning (Teori dan Aplikasi PAIKEM). Yogyakarta: Pustaka Pelajar.

Sutirjo dan Sri Istuti Mamik. (2005). Tematik: Pembelajaran Efektif dalam Kurikulum 2004. Malang: Bayumedia Publishing.

Tirtaraharja, Umar dan Sulo La Lipu. (2005). Pengantar Pendidikan. Jakarta: Rineka Cipta.

Trianto. (2010). Model Pembelajaran Terpadu. Jakarta: Bumi Aksara.

Wardani, Naniek Sulistya, dkk,. (2012). Asesmen Pembelajaran SD. Salatiga: Widya Sari Press.

Widoyoko, Eko Putro. (2012). Teknik Penyusunan Instrumen Penelitian. Yogyakarta: Pustaka Belajar.

Yamin, Martinis. (2003). Strategi Pembelajaran Berbasis Kompetensi. Jambi: Ganung Persada Press. 